\title{
PCR and qPCR-based applications in rumen microbiology research: a review
}

\author{
Malgwi Isaac Hyeladi1,2, János Tossenberger ${ }^{1}$, Veronika Halas ${ }^{1}$, \\ György Végvári², Melinda Kovács ${ }^{2,3}$, Ildikó Jócsák²*
}

${ }^{1}$ Department of Animal Nutrition, Faculty of Agriculture and Environmental Sciences, Kaposvár University, Guba Sándor u. 40. H-7400, P.O. Box 16, Kaposvár-Hungary

${ }_{2}^{2}$ Institute of Physiology, Biochemistry and Animal Health, Kaposvár University, Guba Sándor u. 40. H7400, P.O. Box 16, Kaposvár-Hungary

${ }^{3}$ MTA-KE Mycotoxins in Food Chain Research Group, Kaposvár University, Guba Sándor u. 40. H7400, P.0. Box 16, Kaposvár-Hungary

\begin{abstract}
The rumen and its microbial ecosystem play a central role in the overall nutrition and health of ruminant animals. However, development and homeostatic state of the entire gut system is influenced by different interrelated factors. Recent developments in molecular diagnostic tools by using amplicon sequencing of $16 \mathrm{~S}$ ribosomal RNA and use of high-throughput data generated through applications of pyrosequencing is a promising approach to defining the rumen microbial genome. Several "omic"-based technologies based on PCR and real-time PCR (qPCR), are currently being used in gut microbiology in order to predict how the gut microbiota works. Such procedures include pyrosequencing, genome-wide shotgun sequencing, short metagenomics sequencing and metagenomics analysis, bacterial DNA integration for editing genomes of isolated microbes, etc. These tools are sensitive and precise in quantitation, identification and functional characterisation of the entire rumen microbiome. PCR/qPCR enables investigations of changes in the microbiome and microbiota with respect to age, diet, species and environmental variations thus providing new information about rumen microbial genome. In this review, we will highlight recent findings using PCR and qPCR-based procedures in investigating the complex nature of the rumen microbial population which has advanced our knowledge and understanding of the rumen microbial genome.
\end{abstract}

Keywords: Bacteria, Genome, Microbiome, Microbiota, Rumen, PCR/qPCR, 16S rRNA.

\section{INTRODUCTION}

One of the most widely used molecular diagnostic tool since its invention in the twentieth century is the polymerase chain reaction, PCR. PCR amplifies a segment of the DNA, such that millions or even billions of copies of a DNA molecule are generated in a very short time. PCR has been described as a versatile tool with diverse applicability to many different situations in molecular diagnostic research (Barlett and Stirling, 2003). It has also been used to detect DNA sequences, in forensic investigations, DNA fingerprinting, detection of bacteria and viruses to diagnose genetic diseases as well as cloning. PCR is the key that

\footnotetext{
*CORRESPONDING AUTHOR

Kaposvár University, Faculty of Agricultural and Environmental Sciences

$\triangle$ H-7400 Kaposvár, Guba S. str. 40., 正 +36-82-505-800

E-mail: jocsak.ildiko@ke.hu
} 
unlocked several advances made in our understanding of the genome of human, bacteria and other species (Mullis et al., 1986; Innis and Galfand, 1990).

Bacteria, protozoa and anaerobic fungi have been implicated as key degraders of polysaccharides in the rumen (Schofield, 2000). They are found in all the four compartments of ruminants gut (rumen, reticulum, omasum and abomasum). Microbiologically, the rumen is said to be made up of a complex ecosystem which is composed of cells $/ \mathrm{ml}$ concentrations of about $10^{10}, 10^{6}$ and $10^{4}$ for bacteria, fungi and protozoa respectively, which interact in synergy and are active throughout the process of digestion and fermentation. This synergistic interaction also augment enzymatic digestion process in the animal for energy generation and yields volatile fatty acids (VFAs): acetate, butyrate, propionate, as well as other compounds such as ammonium, formic acid, methane gas, $\mathrm{H}_{2}$, as well as $\mathrm{CO}_{2}$ as end products of rumen fermentation (Krause et al., 2003; Pitta et al., 2010; Stewart and Bryant, 1988). Biomass-degrading enzymes encoded in the rumen microbiome and proteins belonging to bacterial and archaeal genomes have been associated with carbohydrate metabolism (Stewart et al., 2018).

Different bacterial groups function as one unit and assist the host (ruminants) degrade and utilize fibrous feed stuff in order to make volatile fatty acids as a source of energy from plant structural and nonstructural carbohydrates and proteins. Noteworthy, due to their relative abundance and metabolic diversity, Fibrobacter succinogenes, Ruminococcus albus and Ruminococcus flavefaciens (Hungate, 2013; Zhou et al., 2015) are main cellulolytic bacteria associated with ruminal digestion of plant cell wall materials whereas Ruminobacter amylophilus or Prevotella ruminicola dominates the degradation of starch (Steward and Bryant, 1988; Mobashar et al., 2019). Amino acids, soluble proteins and insoluble, particulate proteins are primarily degraded by bacteria and protozoa respectively (Cotta, 1998; Hino and Russel, 1987; Foroozandeh et al., 2009; Russell, 2009) while protozoa were reported to be limited in their ability to assimilate peptides (or amino acids) (Hino and Russel, 1987).

Classical culture-based procedures which are applied in isolation, identification and quantitation of rumen microbes have been reported to account for less than $30 \%$ of the rumen microbial population. This is because several rumen microbes have shown tendencies of bypassing or escaping conventional culturing procedures and this necessitates the application of enhanced and more sensitive techniques (Nathani et al., 2013). However, recent developments in molecular diagnostic tools and use of high-throughput data generated 
through applications of next-generation sequencing, pyrosequencing of bacterial 16S ribosomal RNA gene has provided wider understanding of the operations and activities of rumen resident microbes. Additionally, genome-wide shotgun sequencing for metagenomic data generation have revealed new information and innovative research areas about the function, characteristics and diversity of rumen microbiota. This has provided linkage between functional gene activity, metabolic pathways and rumen metabolites (Nathani et al., 2013; McCann et al., 2014; Roehe et al., 2016; Denman et al., 2018; Stewart et al., 2018). Research in rumen microbiome is quite complicated and consists of different areas which provides a wide range of research possibilities. Figure 1 shows some of these areas that are PCR/qPCR-based procedures in analysing, characterising or quantitating the microbial diversity in the rumen.

\section{Development of Rumen Microbiota}

Microbial genomes remain unchanged for life while the microbiome profiles tends to change as the new born animal grows (Goodrich et al., 2017). The rumen and its microbial ecosystem play a central role in the overall nutrition and health of the animal. However, development and homeostatic state of the entire gut system is influenced by different interrelated factors. These factors include genetic, physiological and environmental factors which may include dietary variations (quality and quantity), age, and maternal factors among others, are central in determining how the microbial population carryout their functions in supplying energy and nutrient to the animal as well as providing information about the variation in microbial diversity within the rumen microbiome (Callaway et al., 2010; Callaway et al., 2011; De Menezes., et al., 2011; Tymensen et al., 2012; Han et al., 2015; Dang et al., 2017).

Microbiologically, the rumen could generally be said to be made up of a complex ecosystem which is composed of cells $/ \mathrm{ml}$ concentrations of about $10^{10}, 10^{6}$, and $10^{4}$ for bacteria, fungi and protozoa respectively (Hungate, 1966; Skillman et al., 2006; Jewell et al., 2015), these microbes interact in synergy and are active throughout the process of digestion. Their synergistic interaction and effects tend to influence immunological responses, gut health and also augment enzymatic digestion process in the animal. As such, they are active in generating volatile fatty acids (VFAs): acetate, butyrate, propionate, and other compounds such as formic acid, Methane gas, $\mathrm{H}_{2}$, as well as $\mathrm{CO}_{2}$ for utilisation by the animal in energy generation for cellular and metabolic processes. These groups function as one unit and assist the host (ruminants) in degrading and utilising fibrous feed stuff in a symbiotic relationship in order to make volatile 
fatty acids as a source of energy from plant structural and nonstructural carbohydrates and proteins. The significance of the rumen microbiota in ruminant and human nutrition necessitates careful research in order to elucidate their roles and mode of action (Krause et al., 2003; Kamara, 2005; Pitta et al., 2010; Taschuk and Griebel, 2012; Rodríguez et al., 2015; Roehe et al., 2016).

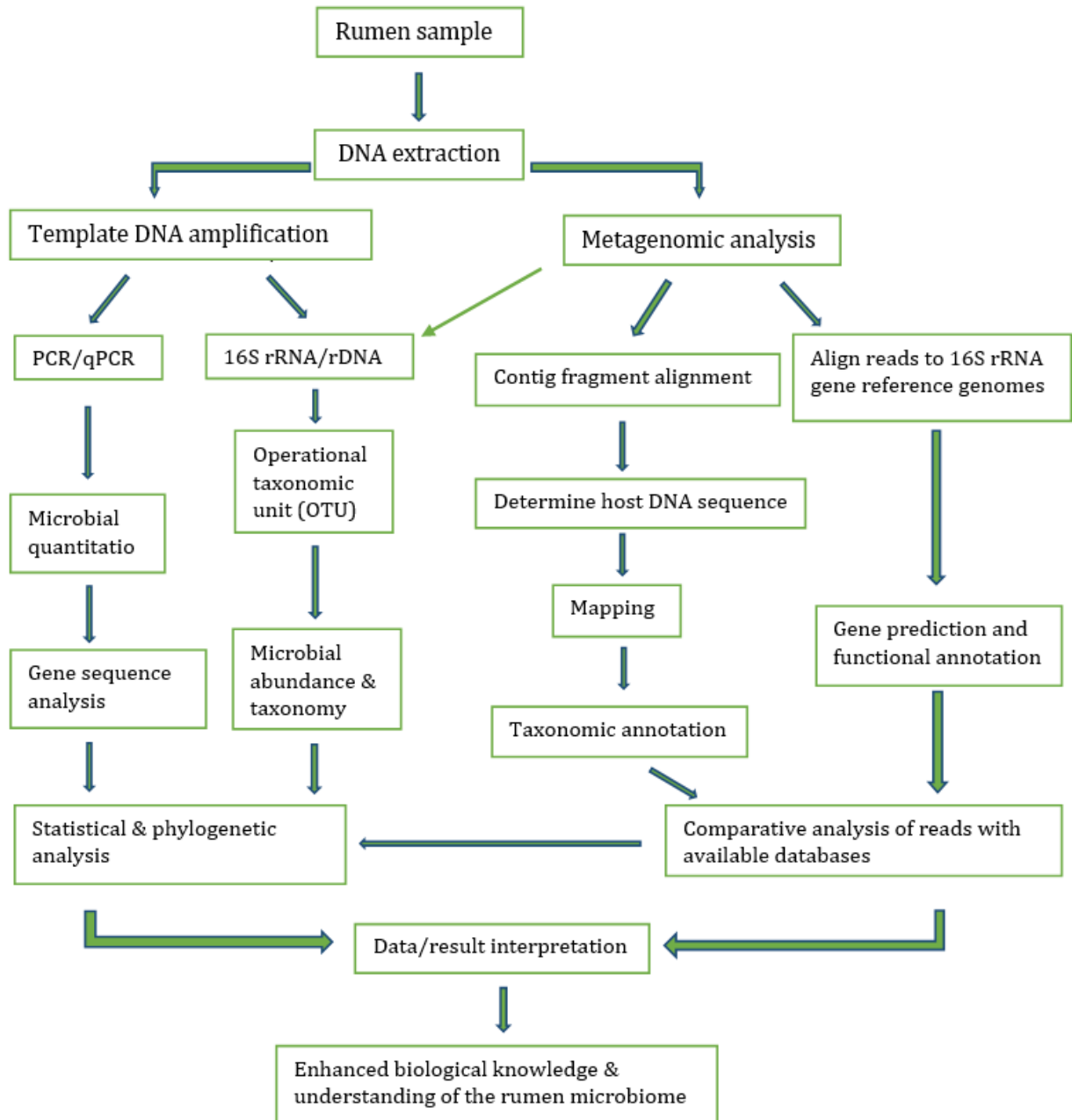

Figure 1: Rumen microbiome project workflow chart (Modified from McCann et al., 2014) 


\section{Microbial Diversity in the Rumen}

\section{Rumen Bacteria}

Rumen development has a significant effect on the microbial diversity of the entire gut system. Bacteria are the most dominant and diverse microbial community in the rumen. Flint et al. (2008) reported that bacteria are the most diversified groups of microbes in the rumen, approximately $95 \%$ of total microbiota. Subsequent studies involving rumen microbiology revealed a very large number of bacteria present in the rumen (up to about $10^{11}$ viable cells/ml) (Kim et al., 2011; Jami and Mizrahi, 2012b). Since new born ruminants generally have no functional rumen at birth, development and establishment of the ruminal microbiota still has various controversies by so many researchers (Hungate, 1966; Jewell et al., 2015). As the young ruminant grows, the species and bacterial community also experience a shift in composition ( $\mathrm{Li}$ et al., 2012). Fibrobacter succinogenes, Ruminococcus albus and Ruminococcus flavefaciens were quantified using real-time PCR targeting $16 \mathrm{~S}$ rDNA and the results showed that $R$. flavefaciens was slightly more dominant compared to $F$. succinogenes with the population of $R$. flavefaciens and $F$. succinogenes are significantly more than $R$. albus species (Mosoni et al., 2007).

\section{Rumen Protozoa}

Protozoa play a key role in the hydrogen transfer between microbial species and methane production within the rumen microbiome (Salonen et al., 2014). Ciliates have been reported to be the most abundant protozoa resident in the rumen of both domesticated and wild ruminants, contributing to fiber digestion, control of $\mathrm{CHO}$ fermentation process and the possibility of having a negative effect on protein metabolism. Until the application of PCR in rumen microbiological studies, rumen protozoa was quantified based on a microscopic count and this has shown that the most abundant genus accounting for about $95 \%$ of the total protozoal population in the rumen, is the genus Entodinium. However, comparing microscopic analysis with PCR based protocols has shown that there are several species and genera of protozoans which are resident in the rumen and are yet to be fully characterised (Regensbogenova et al., 2004; Skillman et al., 2006; Sylvester et al., 2009; Tymensen et al., 2012). This necessitates the need to intensively investigate protozoal populations in the rumen because they play significant role in fiber digestion and have negative effect on microbial protein turnover. However, they have been reported to have variation in the number of their rDNA copies per cell during a life cycle and also their cell sizes vary inter and intra-protozoal specie (Prescott, 1994; 
Dehority, 2003; McSwansea et al., 2007). A major limitation of real-time PCR in microbial quantitation as well as protozoal analysis is that qPCR-based approach is more expensive than microscopic counts procedures. However, qPCR is more sensitive and more accurate with the ability to detect 1 to 10 million protozoal cells using genus specific primers that was developed by Skillman and co-workers for detection of Entodinium (Skillman et al., 2006).

\section{Fungi}

Fungi initiate mechanical and enzymatic break down of plant fiber to allow access for secondary metabolisers (Boots et al., 2013). Anaerobic rumen filamentous fungi form extensive interlocking rhizoidal systems. Accurate quantification and identification within this group of microbes by direct count using culture-based protocols are difficult, especially when considering that environmental samples contain both polycentric and monocentric species (Denman and McSweeney, 2006). Six genera, Neocallimastix, Piromyces, Anaeromyces, Caecomyces, Orpinomyces, and more recently Cyllamyces, have been recognized, while 18 species of anaerobic rumen fungi have been described on the basis of their thallus morphology and their zoospore ultrastructure (Liggenstoffer et al., 2010; Chaucheyras-durand and Ossa, 2014). However, investigation using PCR-based high-throughput sequencing technology has revealed several uncultured taxa and the relative abundance of the rumen fungal populations estimated to be $10 \%$ of the total microbial biomass, with large variations according to diet and individual (Krause et al., 2013).

\section{Rumen Viromes and Bacteriophages}

The occurrence of bacteriophages in the rumen has previously been documented at $10^{7}$ to $10^{9}$ particles per ml. About 28,000 different viral genotypes were identified using PCR-based protocols. Despite the possibility of isolating and storing several rumen phages in culture collections, particularly in the 1970's and 1980's, it was reported that only those phages with applicability in genetic engineering and phage therapy were successfully characterised beyond an initial assessment on the basis of morphology (Gilbert and Klieve, 2015). DNA sequencing and the advent of metagenomic studies to comprehensively sequence phage particle fractions obtained from rumen fluid as well as the full extent of viral diversity within the rumen based on "omic" applications is gradually being revealed (Berg Miller et al., 2012). Thus, diverse groups of rumen resident phages were found to have a high tendency of infecting various 
species of rumen bacteria through their tendency for exhibiting lytic replication (Gilbert et al., 2017). However, little information is available about the genetics of phages while their genome has remained largely uncharacterised. Gilbert et al. (2017) reported that bacterial genome sequencing project is a powerful tool which is revealing the presence and activity of phages and their ability to integrate their DNA into the genome of their host to form stable, lysogenic associations. Thus, rumen phages could infect and replicate within the host and the release of progeny phage particles (Gilbert et al., 2017).

\section{Exploring the rumen microbiome using PCR/qPCR}

\section{End point PCR}

Polymerase chain reaction, PCR, is a step-by-step in vitro primer interposing DNA enzymatic amplification process. It is a technique of making millions of copies of a particular DNA target of interest that is being replicated during PCR cycles over a period of time (Ginzinger, 2002; Sluijter et al., 2006). At the last cycle of the reaction, PCR products are detected and analysed using electrophoresis. The amplification process (detection and identification of target DNA) occurs in three stages; denaturation, annealing and elongation stages. Identification is made through visual methods based on size the amplified DNA piece (Freeman et al., 1999; Ginzinger, 2002; Sluijter et al., 2006). Microbial PCR procedures have been optimised using primers targeting V2 - V4 regions of the 16 rRNA gene. Recently, pathophysiological examination in sheep by comparing resident microbiome in the upper aerodigestive and lower respiratory tracts of lambs, PCR was used to amplify the V2-V3 region of the 16S rRNA gene and subsequently sequenced via Illumina Miseq which revealed oropharyngeal swabs were either dominated by bacteria commonly associated with the rumen or by bacteria commonly associated with the upper aerodigestive tract (Glendinning et al., 2017). Similarly, PCR procedures have been optimised using primers targeting the V4 and V3-V4 region of the 16S rRNA gene under 20 and 28 PCR identical cycle conditions for amplicon sequencing to generate a relatively accurate representation of rumen microbiome (McGovern et al., 2018).

\section{RT-PCR; qPCR}

Real time PCR is also known as quantitative PCR (qPCR), depending on the application. The greatest advantage real-time PCR reaction compared to endpoint PCR is the possibility to determine concentration of the targeted DNA fragment as the template DNA is being synthesized. This makes data to be collected throughout the PCR process providing the possibility to view the entire 
reaction and product generation, also combining the amplification and detection in one step (Suzuki et al., 2000; Rasmussen, 2001; Wong and Medrano, 2005; Sluijter et al., 2006; Yibing, 2012; Alvarez and Doné, 2014). In qPCR, a major feature is the point during amplification at which PCR product accumulation is first detected instead of quantitation of PCR product after a defined number of cycles. Results from real-time PCR can be both quantitative and qualitative. In the latter case, it is possible to visualise the melting curve of a DNA of interest after amplification, which can prove the presence or absence of the gene of interest and specificity of the reaction and not the amount of DNA present in a given sample (Sluijter et al., 2006; VanGuilder et al., 2008; Malmuthuge et al., 2014; Glendinning et al., 2017).

Rumen microbial composition consist of bacteria, archaea, ciliate protozoa, fungi, bacteriophage and viruses. Over 200 species of bacteria (approximately $10^{10}-10^{11}$ cells $/ \mathrm{ml}$ ) and 100 species of protozoa and fungi are found in the rumen. However, despite their abundance and significant roles in fermentation and microbial digestion in the rumen, it was difficult to have them cultured, identified or characterised using conventional culture-based methods. There are many several species and groups of bacteria, protozoa and fungi which tend to influence different physiological processes such as Fibrobacter succinogens, Lactobacillus ruminis, Escherichia coli, anaerobic chytridiomycete fungi, Peste des petits ruminants, rinderpest, etc in ruminants (Chaucheyrasdurand and Ossa, 2014; Bainbridge et al., 2016; Mathew et al., 2018). These identified microbial species could vary with diet, genetics and environment (Benson et al., 2010; Uyeno, 2010; Kim et al., 2012; Henderson et al., 2015). The use of PCR and qPCR in microbial investigations have evinced that the abundance of rumen bacteria is up to about $1012 \mathrm{cell} / \mathrm{ml}$ (Kim et al., 2011; Jami and Mizrahi, 2012b). With real-time PCR, the number of isolated bacterial species has been significantly increased and was found to play salient roles in the rumen (Denman et al., 2018). Similarly, 16S rRNA-gene-targeted specific primers for analysis of caecal microbial community using qPCR revealed how dietary supplements and age influenced amount of the copy number of each bacterium (total bacteria, Bacteroides and Clostridia) found in the caecum (Bagóné Vántus et al., 2018). A peculiar feature of the real-time PCR is that the bacterial and total microbial populations can be measured concurrently, this is important when dealing with heterogeneous rumen samples (Skillman et al., 2006).

Application of optimised and sensitive protocols based on the use of PCR/qPCR has identified and characterised several rumen microbes which 
have shown tendencies of by-passing or escaping conventional culturing procedures thus providing accurate and more detailed information about the nature of microbial diversity and interaction that exist within and between rumen microbial populations (Nathani et al., 2013).

Bacterial Diversity:

Phylogenetic analysis of the bacterial communities that colonise the gut system of pre-weaned calves by Malmthuge et al., (2014), revealed that a total of 83 genera belonging to 13 phyla with Firmicutes, Bacteroidetes, and Proteobacteria predominating the gastro intestinal tract of the calves under investigation. Subsequently, qPCR analysis of the selected dominant bacterial genera (Prevotella, Bacteroides, Lactobacillus, and Faecalibacterium) in the same study revealed that, the occurrence of the identified bacterial genera varies significantly with different locations of the gastro intestinal tract as well as between bacteria found on the mucosa and in the rumen digesta (Malmthuge et al., 2014). These findings were consistent with Henderson et al. (2015), who used a qPCR-based sequencing procedures and reported that Bacteroidetes, Firmicutes, and Proteobacteria constitute the most dominant bacterial phyla in the rumen while subsequent phylogenetic analysis of the genomic sequences showed that Prevotella, Butyrivibrio, and Ruminococcus, as well as unclassified Lachnospiraceae, Ruminococcaceae, Bacteroidales, and Clostridiales are a "core bacterial microbiome" at the genus level (Henderson et al., 2015). Similarly, data from pyrosequencing of the bovine rumen bacterial 16S ribosomal rDNA gene sequences evince that the average composition of the rumen bacterial community consisted mainly of the phyla Bacteroidetes and Firmicutes, 51\% and $43 \%$ of all reads, respectively while Proteobacteria accounted for $5.455 \%$ of the reads (Kim et al., 2011; Jami and Mizrahi, 2012). Molecular diversity of methanogens in the rumen of goats investigated with 16S rRNA gene clone libraries which consist of rumen fluid-associated methanogens (FAM) and rumen particle-associated methanogens (PAM) using methanogen-specific primers. The data obtained from the qPCR results shows that there is a significant difference in the concentration of methanogens in the two investigated groups, PAM (8.97 log 10) > FAM (7.57 log 10) (Gu et al., 2011). Recently, several bacteria has been identified which are significantly more abundant in lung fluids than in the upper aerodigestive tract swabs in sheep; Staphylococcus equorum was reported to be most predominant (Glendinning et al., 2017). 


\section{Protozoal Diversity:}

Real-time PCR is more sensitive than microscopic count when it comes to protozoal detection and quantification because with qPCR, upto about 1-106 cells/ml protozoa is detectable (McSwasea et al., 2007). Cell counts and realtime PCR has been applied in quantifying total rumen protozoa and different genera of rumen protozoa on the basis of morphology (microscopy) or primer choice (real-time PCR) (Skillman et al., 2006). Diversity of the rumen protozoa using protozoa-specific PCR primers revealed that major protozoal species found in the rumen includes Epidinium caudatum, Entodinium caudatum, and Isotricha prostoma (Sylvester et al., 2004). Tymensen et al. (2012) compared protozoan communities from hay-fed cattle and silage-grain-fed cattle using TRFLP analysis and the outcome yielded similar overall results to data obtained from microscopic analysis; it was concluded that Entodinium was the predominant genus of rumen protozoa present in all cattle regardless of diet, accounting for $94.2 \%$ of protozoa in silage/grain-fed cattle versus $57.4 \%$ for hay-fed cattle (Skillman et al., 2006; Tymensen et al., 2012). Apart from Entodinium, which has been reported to be dominant in the rumen, large phylogenetic diversity was found from a few numbers of sequenced clones. Protozoa that inhabit the rumen were detected by PCR using protozoan-specific primers based on the $18 \mathrm{~S}$ rDNA sequences in the rumen contents of cow and the predominant protozoan genus identified in the whole rumen belonged to the Entodinium group (81.1\%) (Karnati et al., 2003; Shin et al., 2004). Entodinium accounted for about $98 \%$ of the total protozoa, and populations within the same sheep were relatively stable, but greater variation occurred among individual sheep $\left(10^{0}\right.$ and $10^{6}$ Entodinia per gram of rumen contents).

\section{Fungal Diversity:}

Earlier attempts using the PCR/qPCR in order to quantitate rumen fungi has shown that there is high level of conservation within fungal 18S rDNA gene sequences and a more appropriate target for identification known as the internal transcribed spacer 1 region (ITS1) has been proposed to be targeted. ITS1 is located between the 18S rDNA and 5.8S rDNA genes and this region. It was identified as containing high levels of sequence variation, and it is used for the phylogenetic identification of anaerobic rumen fungi using qPCR-based techniques (Bowman et al., 1992; Li and Heath, 1992; Brookman et al., 2000; Edwards et al., 2008). Phylogenetic diversity of the gut anaerobic fungi was investigated in 30 different herbivore species by Liggenstoffer et al. (2010) using the 
internal transcribed spacer region 1 rRNA in addition to a total of 267,287 sequences representing all known anaerobic fungal genera were obtained. The study revealed that sequences related to the genus Piromyces are predominant in rumen, which is about $36 \%$ of the total sequences obtained. Other sequences were related to the genera Cyllamyces and Orpinomyces and were categorised as the least abundant, representing 0.7 and $1.1 \%$ of the total sequences obtained, respectively. Subsequently, 38.3\% of the sequences obtained did not cluster with previously identified genera and formed 8 phylogenetically distinct novel anaerobic fungal lineages (Liggenstoffer et al., 2010). qPCR also revealed significant reduction in the relative abundance of fungi with respect to diet and dietary additives (Tapio et al., 2017).

\section{Rumen Bacteriophage:}

Bacteriophages have significant role in maintaining rumen microbial balance (Berg Miller et al., 2012) and assisting the progress of horizontal gene transfer in the rumen microbiome (Rohwer et al., 2009; Berg Miller et al., 2012). There is an association between bacteriophage and microbial populations in the rumen evinced by sequence similarities that between the rumen viromes and the rumen microbiome. The application "omic"-based procedures have shown that most abundant rumen bacteriophage and prophage have been reported to be closely associate with several members of the rumen dominant bacterial phyla, Firmicutes, Bacteroidetes, and Proteobacteria (Brulc et al., 2009; Berg Miller et al., 2012). Berg Miller et al., (2012) reported that total DNA isolation from a phage-enriched fraction of rumen fluid and subsequent pyrosequencing of the total rumen virus-enriched metagenome (virome) revealed that rumen microbial genomes tend to share some sequence similarity to rumen viruses (phages) and prophage which also agrees with earlier findings which suggests transfer of genetic information between the microbial and viral populations within the rumen (Brulc et al., 2009) while prophages have been reported to be more numerous than lytic phages by approximately 2:1(Berg Miller et al., 2012).

\section{Taxa Specific Oligonucleotide (Primer) Sequences for PCR}

Application of real-time PCR in rumen microbiology using species-specific bacterial PCR primers (Table1) have been developed. Each pair of PCR primer sequence targets the 16S rRNA gene for detection and quantification of bacteria from diverse species within the rumen microbiome (Khayalethu, 2013). Also, these primer sets have been applied in studying the bacterial variation of microbial population based on DNA copy numbers in relation to changes in diet, 
gut physiology of the animal as well as environmental conditions (Tajima et al., 2001; Kamra, 2005). The most frequently used primers for PCR/qPCR-based investigations of various bacteria, fungi, protozoa and archea species as shown by several studies are presented in Table 1 and 2 .

\section{Application of "omic" procedures with PCR/qPCR to rumen microbial di- versity}

Application of PCR/qPCR "omic"-based procedures has enhanced investigation of rumen microbiome over the past few years. Whole-genome sequencing, pyrosequencing, proteomics (metagenomic-proteomic), transcriptomics has provided a clearer insight into composition, functionality and diversity of each rumen microbial species (Morrison et al., 2003; Roesch et al., 2007; Dowd et al., 2008; Brulc et al., 2009; Callaway et al., 2010; Iakiviak et al., 2011; RansomJones et al., 2012; Krause et al., 2013). Associations between microbial genes and the host animal could provide information on microbiome genotype-environment interaction using genome wide association studies, GWAS, in order to predict genetic predisposition to disease or performance among species (Goodrich et al., 2017). Such DNA technologies are the basis of current rumen microbiological research and are revealing information about the true nature of the rumen microbiome. Basic concept underlying analysis of rumen microbiome on the basis of taxonomic structure, diversity, function, and sequence analysis methodology has been described by the rumen microbiome project workflow shown on Figure 1 (Di Bella et al., 2013; McCann et al., 2014).

\section{Metagenomics and Metatranscriptomics}

Estimation of functional and fractional potentials of DNA and RNA can be achieved through the application of metagenomic and metatranspriptomic analysis. Such analysis are carried out using bioinformatics tools in order to study genetic materials from uncultured microorganisms. These tools have proven to be efficient in characterising the rumen microbiota according to function on the basis of their genomes as well as high throughput analysis of amplified taxonomic marker genes (Li et al., 2017). In metagenomics, the template DNA is sequenced without prior amplification of specific genes which results in a snapshot of the gene pool and functional potential of the microbiome while in transcriptomics, mRNA is analyzed to provide a measure of gene expression within the intestinal microbiome (Suchodolski, 2012). A deeper and clearer insight into taxonomic and functional characteristics of the rumen mi- 
crobiome and its interaction with the environment offers researchers the opportunity to optimize the digestion process in the rumen for enhanced and efficient sustainable utilization of dietary nutrients (Walsh et al., 2017).

Metagenomic and metatranscriptomic inventions are considered more accurate and are widely used with conventional PCR and qPCR based protocols for routine identification, for result justifications and taxonomic assessment of the microbiota (Urich et al., 2008; Hong et al., 2009; Huber et al., 2009; Ross et al., 2012). The use of $16 \mathrm{~S}$ rDNA sequences generated in metagenomics datasets sequencing procedures based on specific targeted marker genes and transcripts using 16S bacterial and archaeal rDNA/rRNA, 18S rDNA/rRNA for protozoa, and internal transcribed spacer (ITS) gene/transcript for fungi has been reported to be the basis of classification and phylogenetic analysis of rumen microbiome (Deng et al., 2007; Ellison et al., 2014).

Metagenomics and metatranscriptomics are fast, reliable, less expensive with diverse applicability. It has been applied in soils, water and animal-based samples. However, as a result of the low fraction of $16 \mathrm{~S}$ rDNA reads present in metagenomics datasets, most metagenomic studies rely on analogous DNA amplicon sequence to characterise microbial populations (Urich et al., 2008; Baker et al., 2013; Martínez et al., 2013 Franzosa et al., 2014; Logares et al., 2014; Mason et al., 2014; Rooks et al., 2014; Tveit et al., 2014; Li et al., 2016). To characterise biomass-degrading genes and genomes, 268 gigabases of metagenomic DNA from rumen microbes (which are viscid to plant fiber incubated in cow rumen), Hess et al., identified 27,755 putative carbohydrate-active genes and 90 expressed candidate proteins, of which $57 \%$ were enzymatically active against cellulosic substrates (Hess et al., 2011). However, recent studies reported that the rumen microbes are under-represented in the public databases (Li et al 2017; Stewart et al., 2017; Stewart et al., 2018). From these recent studies, 220 high quality bacterial and archaeal genomes assembled directly from 768 gigabases of rumen metagenomic data were presented and the comparative analysis of these sequences against current publicly available genomes shows that over $90 \%$ of these sequences represent previously non-sequenced strains and species of bacteria and archaea. The genomes contain over 13,000 proteins predicted to be involved in carbohydrate metabolism in the cow rumen. Furthermore, rumen virome has been explored using metagenomics and metatranscriptomics in dairy cattle and the results have shown that the rumen virome is composed of highly diversified and vast number of phages (Berg Miller et al., 2012). 


\section{Table 1}

PCR Primer sequences for detection of rumen bacteria, arachea and methanobacteriales

\begin{tabular}{|c|c|c|c|c|}
\hline $\begin{array}{l}\text { Target } \\
\text { bacterium }\end{array}$ & Primer sequence $\left(5^{\prime}-3^{\prime}\right)$ & $\begin{array}{l}\mathrm{AT} \\
\left({ }^{\circ} \mathrm{C}\right)^{*}\end{array}$ & $\begin{array}{l}\text { Ps } \\
\text { (bp)** }\end{array}$ & References \\
\hline Total bacteria & $\begin{array}{l}\text { Forward: CCTACGGGAGGCAGCAG } \\
\text { Reverse: ATTACCGCGGCTGCTGG }\end{array}$ & 60 & 194 & $\begin{array}{l}\text { (Muyzer et al., 1993; Mo- } \\
\text { soni et al., 2007) }\end{array}$ \\
\hline $\begin{array}{l}\text { Streptococcus } \\
\text { bovis }\end{array}$ & $\begin{array}{l}\text { Reverse: CTAATACCGCATAACAGCAT } \\
\text { Forward: AGAAACTTCCTATCTCTAGG }\end{array}$ & 57 & 869 & (Tajima et al., 2001) \\
\hline $\begin{array}{l}\text { Eubacterium } \\
\text { ruminantium }\end{array}$ & $\begin{array}{l}\text { Forward: GCTTCTGAAGAATCATTTGAAG } \\
\text { Reverse: TCGTGCCTCAGTGTCAGTGT }\end{array}$ & 57 & 671 & (Tajima et al., 2001) \\
\hline $\begin{array}{l}\text { Fibrobacter } \\
\text { succinogenes }\end{array}$ & $\begin{array}{l}\text { Forward: GGTATGGGATGAGCTTGC } \\
\text { Reverse: GCCTGCCCСTGAACTATC }\end{array}$ & 60 & 446 & $\begin{array}{l}\text { (Tajima et al., 2001; } \\
\text { Wanapat \& Cherdthong, } \\
\text { 2009) }\end{array}$ \\
\hline $\begin{array}{l}\text { Ruminococcus } \\
\text { albus }\end{array}$ & $\begin{array}{l}\text { Forward: CCCTAAAAGCAGTCTTAGTTCG } \\
\text { Reverse: CCTCCTTGCGGTTAGAACA }\end{array}$ & 60 & 175 & $\begin{array}{l}\text { (Koike \& Kobayashi, } \\
\text { 2001; Khampa et al., } \\
\text { 2006) }\end{array}$ \\
\hline $\begin{array}{l}\text { Ruminococcus } \\
\text { flavefaciens }\end{array}$ & $\begin{array}{l}\text { Forward: GGACGATAATGACGGTACTT } \\
\text { Reverse: GCAATCYGAACTGGGACAAT }\end{array}$ & 62 & 835 & (Tajima et al., 2001) \\
\hline $\begin{array}{l}\text { Ruminobacter } \\
\text { amylophilus }\end{array}$ & $\begin{array}{l}\text { Forward: CAACCAGTCGCATTCAGA } \\
\text { Reverse: CACTACTCATGGCAACAT }\end{array}$ & 57 & 642 & (Tajima et al., 2001) \\
\hline $\begin{array}{l}\text { Prevotella } \\
\text { bryantii }\end{array}$ & $\begin{array}{l}\text { Forward: AGTCGAGCGGTAAGATTG } \\
\text { Reverse: CAAAGCGTTTCTCTCACT }\end{array}$ & 68 & 540 & $\begin{array}{l}\text { (Tajima et al., 2001; } \\
\text { Wanapat \& Cherdthong, } \\
\text { 2009) }\end{array}$ \\
\hline $\begin{array}{l}\text { Prevotella } \\
\text { ruminicola }\end{array}$ & $\begin{array}{l}\text { Forward: GGTTATCTTGAGTGAGTT } \\
\text { Reverse: CTGATGGCAACTAAAGAA }\end{array}$ & 53 & 485 & $\begin{array}{l}\text { (Tajima et al., 2001; } \\
\text { Wanapat \& Cherdthong, } \\
\text { 2009) }\end{array}$ \\
\hline $\begin{array}{l}\text { Anaerovibrio } \\
\text { lipolytica }\end{array}$ & $\begin{array}{l}\text { Forward: TGGGTGTTAGAAATGGATTC } \\
\text { Reverse: CTCTCCTGCACTCAAGAATT }\end{array}$ & 57 & 597 & $\begin{array}{l}\text { (Tajima et al., 2001; } \\
\text { Wanapat \& Cherdthong, } \\
\text { 2009) }\end{array}$ \\
\hline $\begin{array}{l}\text { Ruminobacter } \\
\text { amylophilus }\end{array}$ & $\begin{array}{l}\text { Forward: CAACCAGTCGCATTCAGA } \\
\text { Reverse: CACTACTCATGGCAACAT }\end{array}$ & 57 & 642 & $\begin{array}{l}\text { (Tajima et al., 2001; } \\
\text { Wanapat \& Cherdthong, } \\
\text { 2009) }\end{array}$ \\
\hline $\begin{array}{l}\text { Selenomonas } \\
\text { ruminantium }\end{array}$ & $\begin{array}{l}\text { Forward: TGCTAATACCGAATGTTG } \\
\text { Reverse: TCCTGCACTCAAGAAAGA }\end{array}$ & 57 & 513 & $\begin{array}{l}\text { (Tajima et al., 2001; } \\
\text { Wanapat \& Cherdthong, } \\
\text { 2009) }\end{array}$ \\
\hline $\begin{array}{l}\text { Treponema } \\
\text { bryantii }\end{array}$ & $\begin{array}{l}\text { Forward: ACTGCAGCGCGAACTGTCAGA } \\
\text { Reverse: ACCTTACGGTGGCAGTGTCTC }\end{array}$ & 57 & 412 & $\begin{array}{l}\text { (Tajima et al., 2001; } \\
\text { Wanapat \& Cherdthong, } \\
\text { 2009) }\end{array}$ \\
\hline Total arachea & $\begin{array}{l}\text { Forward: GYGCAGCAGGCGCGAAA } \\
\text { Reverse:GGACTACCSGGGTATCTAAT }\end{array}$ & & $415-420$ & $\begin{array}{l}\text { (Takai and Horikoshi } \\
\text { 2000) }\end{array}$ \\
\hline $\begin{array}{l}\text { Methano- } \\
\text { bacteriales }\end{array}$ & $\begin{array}{l}\text { Forward: CGAAGGGAAGCTGTTAAGTC } \\
\text { Reverse: TACCGTCGTCCACTCCTTC }\end{array}$ & & 343 & (Yu et al., 2005) \\
\hline
\end{tabular}

*Annealing Temp., **Product size 


\section{Table 2}

PCR primer sequences for detection of fungi and protozoa

\begin{tabular}{llcc}
\hline $\begin{array}{l}\text { Target } \\
\text { microbe }\end{array}$ & Primer sequence $\left(5^{\prime}-3^{\prime}\right)$ & Ps $(\mathrm{bp})^{*}$ & References \\
\hline $\begin{array}{l}\text { General anaerobic } \\
\text { Fungi }\end{array}$ & $\begin{array}{l}\text { Forward: GAGGAAGTAAAAGTCGTAACAAGGTTTC } \\
\text { Reverse: CAAATTCACAAAGGGTAGGATGATT }\end{array}$ & 120 & (Denman et al., 2006) \\
$\begin{array}{l}\text { Neocallimastigales- } \\
\text { specific primer }\end{array}$ & $\begin{array}{l}\text { Forward: TTGACAATGGATCTCTTGGTTCTC } \\
\text { Reverse: GTGCAATATGCGTTCGAAGATT }\end{array}$ & - & (Edwards et al., 2008) \\
$\begin{array}{l}\text { General } \\
\text { Protozoa }\end{array}$ & $\begin{array}{l}\text { Forward: CAYGTCTAAGTATAAATAACTAC } \\
\text { Reverse: CTCTAGGTGATWWGRTTTAC }\end{array}$ & - & (Sylvester et al., 2004) \\
Ciliate Protozoa & $\begin{array}{l}\text { Forward: TGTCTGGTTAATTCCGA } \\
\text { Reverse: GTGATRWGRTTTACTTRT }\end{array}$ & - & (Isaq et al., 2014) \\
\hline *Product size
\end{tabular}

*Product size

Additionally, cow rumen metatranscriptomic datasets revealed distinct taxonomic and functional signatures in a study by (Jiang et al., 2016) with enzymes involved in amino acid, energy and nucleotide metabolism and also identified microbiome-specific pathways such as phosphonate metabolism and glycan degradation pathways in the rumen. Rumen metagenomic profiling has been used to investigate relative abundance of microbial genes in the gastrointestinal tract of ruminants and could be applied to different species in order to predict influence of microbial composition on traits. Roehe and coworkers (2016) investigated the link between microbial genes, methane emissions and feed conversion efficiency in ruminants using metagenomic analysis and concluded that host microbial composition is an additional reliable basis for selection in animals since the host animal controls its own microbiota (Roehe et al., 2016).

\section{Bacterial 16S rRNA and Next Generation Sequencing (NGS) applications}

Bacterial 16S rRNA gene is common and conversed among bacteria species but vary between taxa and as such, PCR/qPCR-based protocols target the $16 \mathrm{~S}$ rRNA for identification, classification or characterisation of bacteria since decades of PCR application in molecular microbiological procedures (Gutell et al., 1985; Noller, 1984; Ginzinger et al., 2002; Khayalethu, 2013). Next-generation sequencing (NGS) provides high-throughput data for precise and accurate analysis, characterisation and an in-depth examination of the complex rumen microbiome (Shokralla et al., 2012). NGS-based 16S rRNA sequencing is considered cost-effective technique for identifying microbial strains that may not be easily characterised using culture-based methods. Early studies by Gray et al., (1984) highlighted that the bacterial $16 \mathrm{~S}$ gene is composed of about nine hypervariable regions (V1-V9) that ranged from about 30-100 base pairs long 
that are involved in the secondary structure of the small ribosomal subunits. However, the degree of conservation varies widely between hypervariable regions, with more conserved regions correlating to higher-level taxonomy and less conserved regions to lower levels, such as genus and species. Consequently, amplicon sequencing revealed diet specific taxa abundance variations revealing significant differences in protozoal and fungal composition within the rumen of a mature cow (Tapio et al., 2017).

Several studies have explored the sequencing of the $16 \mathrm{~S}$ rRNA gene in evaluating the rumen epithelial bacterial diversity during the development of the rumen and the most dominant phyla detected in the rumen epithelium were found to belong to Proteobacteria, Firmicutes, and Bacteroidetes (Steveson \& Waimer, 2007; Li et al., 2009; Petri et al., 2013; Chaucheyras-durand and Ossa, 2014; Jiao et al., 2015). Additionally, Bacteroidetes has also been reported to be the most abundant phylum in the rumen microbiota, representing upto about $74.8 \%$ of the $16 \mathrm{~S}$ sequences, followed by Firmicutes $(12.0 \%)$, Proteobacteria $(10.4 \%)$, Verrucomicrobia $(1.2 \%)$ and Synergistetes $(1.1 \%)$ and the researchers concluded that the four most abundant phyla in the rumen of matured bull calves which were fed a solid diet are Bacteroidetes $(52.0 \%)$, Firmicutes (42.7\%), Spirochaetes (2.3\%) and Fibrobacteres (1.9\%)(Li et al., 2012).

\section{Pyrosequencing, Illumina Sequencing (MiSeq) and Massively Parallel Sig- nature Sequencing (MPSS)}

Pyrosequencing procedure also enables comparison between and within bacterial species in a given rumen microbiome using 16S rRNA hypervariable regions (approx. 1500 base pairs long) as standard and reliable markers for the taxonomic classification and phylogenetic analysis (Yang et al., 2016). Pyrosequencing is a well optimized procedure for phylogenetic analysis of the complex rumen microbiome (Kim et al., 2011; Klindworth et al., 2013; Yang et al., 2016; Fuks et al., 2018; McGovern et al., 2018). Tewari et al. (2011), showed that utilisation of sequence data from 2 variable regions within the $16 \mathrm{~S}$ rRNA gene: V1 and V6 identified about $80 \%$ of microbes isolated from animals up to the genus level. Similarly, pyrosequencing of hypervariable V3-V5 regions of the 16S rRNA gene and whole-genome shotgun approach to rumen microbiota in pre-ruminant (42-day-old) calves has identified fifteen bacterial phyla in a study conducted by Li et al. (2012). Previously, it has been shown by Tewari et al. (2011) that the differences among different bacterial strains were identified using pyrosequencing. From the strain differential studies, they pointed out that Staphylococcus aureus differs from other Staphylococci while Rhodococcus 
equi also differs from the closely related genus Dietzia spp. Subsequently, pyrosequencing of $S$. bovis identified and differentiated the species from Enterococcus cecorum (Tewari et al., 2011). These findings are consistent with other studies which evinced that deep amplicon sequencing of the $16 \mathrm{~S}$ ribosomal RNA gene have significant differences within the bacterial communities on dietary basis and between rumen solid and liquid contents (Callaway et al., 2010; Callaway et al., 2011; De Menezes., et al., 2011).

Similarly, taxonomic analysis of metagenomic reads from $16 \mathrm{~S}$ rRNA sequences during investigation of the establishment of gut microbial community indicated that the predominant phyla were distinct at different growth stages (Han et al., 2015). They show that phyla Firmicutes and Synergistetes were predominant in rumen samples taken from 80 to 100 -day-old goats. The age of the animals has shown to have significant effect on the abundance of bacterial species. Goats on day 100 showed Bacteroidetes and Firmicutes as most abundant phyla while relative abundance of Firmicutes and Synergistetes was found to be reduced after weaning and Bacteroidetes and Proteobacteria increased with increase with age (from 80 to 110 days). Similarly, Illumina MiSeq platform was used for amplification of the V4 hypervariable region of the 16S rRNA gene from rumen fluid of goats fed the same diet for 20 days. Analysis of the gene sequences using the quantitative insights into microbial ecology pipeline software shows that Bacteroidetes, Firmicutes, Tenericutes were the predominant phylum in both groups, and their relative abundance was $60.63 \%, 29.48 \%$, $2.24 \%$ respectively. Prevotella being the most abundant shared genus between the control and experimental groups (Wang et al., 2018).

Massive parallel signature sequencing (MPSS) procedure is a tool that is used for an in-depth profiling of gene expression pattern through sequencing mRNA transcripts. Bioinformatics tools sort out sequence signature of about 16-20 base pairs generated and identified from each bead by counting the number of individual mRNA molecules produced from each gene (Reinartz et al., 2002). Thus the level of expression of each gene is directly proportional to the number signatures for the gene's mRNA counted. It is highly specific, sensitive (with a level of sensitivity as low as a few molecules of mRNA per sample), and transcripts are captured on individual microbeads through a complementary DNA signature sequence without prior identification and characterization of the gene. This provides wide-range analysis of DNA templates transcribed into an RNA of an entire genome (Brenner et al., 2000; Reinartz et al., 2002; Jongeneel et al., 2005; Rédei, 2008). 
Application of MPSS has also provided deeper insight into rumen microbiological research in recent years. It has possibility of providing accurate predictions that are based on the host genome for traits which are largely influenced by the gut microbiota such as digestive tract disorders, metabolic functions, body mass index (BMI), inflammatory bowel disorder (IBD) and enteric methane production in cattle (Leahy et al., 2013; Ross et al., 2013a). It could also be applied in genomic predictions of complex phenotypes in humans and animals (Ross et al., 2013a). Diversity of the rumen virome in dairy cattle using MPSS revealed strong similarities at functional level between rumen viral samples, which were highly distinct from the rumen microbiome samples. Significant variation between animals living in different housing while animals housed together presented similar viromes (Bathe et al., 2003). Ross and coworkers also observed large effects of feed additives on the rumen microbiome profiles using MPPS (Ross et al., 2013b). Recently, Earl et al., (2018), analysed the $16 \mathrm{~S}$ rRNA microbiome surveys using massively parallel DNA sequencing technologies and reported an increased taxonomic and phylogenetic resolution with species-level classification of $>90 \%$ of taxa and relative abundances microbial population have been reported. They concluded that application of MPSS to marker genes could help enhance taxonomic assignments of microbial species and reference databases and subsequently increase the specificity of relationship between microbial communities (Earl et al., 2018).

\section{Non-PCR based next generation sequencing technology}

With recent advancements in NGS, several PCR-independent NGS technologies have evolved which does not require prior DNA amplification using PCR. Some of these emerging sequencing technologies include single molecule sequencing with Heliscope single molecule sequencer, PacBio single molecule realtime (PacBio SMRT) sequencer and Oxford nanopore sequencer systems which need no pre-amplification steps. Pacific biosciences single molecule real-time (SMRT) sequencing technology is another molecular microscope with no requirement for template amplification step. It enables single molecule detection using sensitive optics which could spot individual fluorescently labeled nucleotide (Buermans and den Dunnen, 2014). These technologies are reliable, fast and sensitive enough to detect signal and read the DNA sequence of individual molecule template extensions. Thus, providing extension of unamplified molecules with greater flexibility in the kinetics of the sequencing chemistry (Pushkarev et al., 2009; Zhou et al., 2013). llumina shotgun sequencing (such as HiSeq, MiSeq), is another PCR-independent sequencing procedure 
that enables estimation of species composition without PCR as a pre-step (Zhou et al., 2013).

\section{RFLP/T-RFLP and DGGE/TGGE}

Restriction fragment length polymorphism (RFLP), or terminal-restriction fragment length polymorphism (T-RFLP), (allows profiling, but also quantitation of microbiota). Denaturing gradient gel electrophoresis (DGGE), or temperature gradient gel electrophoresis (TGGE), are commonly used PCR based molecular fingerprinting techniques for evaluating microbial community and diversity. T-RFLP uses fluorescent-labelled primer for amplification of bacterial DNA fragments during PCR and this allows profiling as well as quantitation of microbial communities using capillary electrophoresis of PCR products fragmented by size with sequence-specific restriction enzymes. During DGGE analysis, a gel containing a linear gradient of DNA denaturants is used, while TGGE a temperature gradient is used for separation. DGGE/TGGE has short shorter bands ( 20 to 40 bands) though many bacterial phylotypes will have similar or the same melting characteristics. This is a key factor that limits visualisation and evaluation of changes in only predominant bacterial groups. There are possibilities to resect and sequence individual band of interest. These techniques separate the PCR amplicons that were generated with either universal or group-specific primers to yield a profile (fingerprint) of the bacterial community (Suchodolski, 2012).

RFLP has been applied in combination with PCR procedures in comparing the genetic diversity and phylogenetic experiments. Avguštin et al. (1994). aimed to evaluate the nature of diversity that exist among 29 strains of Prevotella ruminicola from the rumen has identified signature oligonucleotides based on $16 \mathrm{~S}$ ribosomal DNA sequences which distinguished the strains related to strains 23T, B(1)4, GA33, and M384, as well as an oligonucleotide that specifically recognised all but one of the Bacteroides and Prevotella strains tested. 5 ammonia hyper-producing (HAP) bacteria, using RFLP of 16S rDNA indicated that isolates differed from the previously described HAP bacteria and 16S rDNA PCR-RFLP-based investigations suggested that ruminal Strptoccocu. bovis diversity may be a diet-dependent phenomenon (Kleive et al., 1999; Jarvis et al., 2001). Regensbogenova et al., (2004b) reported that restriction fragment length polymorphism (RFLP) analysis of PCR amplified 18S rDNA sequences could be applied in identifying different rumen protozoa species. However, researchers were of the opinion that since 18S rDNA sequences among different protozoa are found to be closely related, the phylogenetic resolution of such RFLP analysis remains unclear (McSweeney et al., 2007). 
The crucial element of RFLP as a procedure is the selection of an efficient and suitable restriction enzymes for the analysis and is applied in exploring the composition of individual bacterial species (Dang et al., 2007). Schlegel et al., (2003), used two strains of streptococcus, S. bovis and S. equinus which are important intestinal bacterial isolates from human and animal specimens. Schlegel et al. (2003), investigated the nature of the diversity of large bacterial complex including different species frequently isolated from infections of humans (Streptococcus gallolyticus, Streptococcus infantarius) or animals (S. bovis, S. equinus, S. alactolyticus). The diversity of strains of $S$. bovis biotype II was analysed, and it was confirmed that they belong to different species, either $S$. equinus or S. infantarius. Tymensen et al. (2012), used T-RFLP to analyse rumen protozoa communities. The protozoa communities from hay-fed and silage/grain-fed cattle were different while multivariate analysis indicated that cattle fed the same diet and housed together (pen mates) tended to have similar protozoa community types.

Analysis of ruminal methanogenic Archaea communities in the rumen using DGGE is an efficient PCR-based technique in revealing the diversity and complexity of the rumen microbial community. It separates PCR products of the same length but differing in sequence since different sequences possess different melting temperatures resulting in contrasting migration behaviour. Additionally, analysis of PCR-DGGE fingerprint and phylogenetic analysis $16 \mathrm{~S}$ rDNA sequences in DGGE profiles were combined to reveal the dominant bacterial communities and compared the variations of such bacterial communities in cattle breed. Leng et al. (2011) (consistent with Yang et al., 2010) shows that the dominant bacteria in the rumen phyla are Firmicutes, Bacteroidetes and Actinobacteria with significant variation in bacterial specie according to the cattle breeds investigated. Székely et al. (2009), compared the accuracy of DGGE and T-RFLP using bacterial diversity in mature compost bacterial community and cloning of environmental $16 \mathrm{~S}$ rDNA and reported that DGGE shows less diversity (15-22 bands per sample) than T-RFLP (20-59 peaks greater than or equal to $1 \%$ of total peak area per sample). However, principal component analysis (PCA), of the DGGE and T-RFLP profiles showed that both molecular fingerprinting techniques gave a similar clustering of the samples.

\section{CONCLUSION}

The development and thorough application of PCR/qPCR DNA-based technologies in rumen microbiology research have provided a deeper insight into the biological understanding of the rumen microbiota. It is precise, more 
reliable and more efficient than traditional, culture-based identification and characterisation of the rumen microbiota. Through the use of PCR/qPCRbased procedures, quantitation of different rumen microbiota as well as analysis of phylogenetic relationship between and within these various microbial constituents in the rumen is achievable. However, it is advisable to optimise these procedures and other "omic"-based technologies used with PCR/qPCR protocols for accurate analysis of the complex rumen microbiome.

\section{ACKNOWLEDGEMENTS}

The publication is supported by the EFOP-3.6.3-VEKOP-16-2017-00005 project. The project is co-financed by the European Union and the European Social Fund.

\section{REFERENCES}

Alvarez, M. L., \& Doné, S. C. (2014). SYBR® green and TaqMan® quantitative PCR arrays: Expression profile of genes relevant to a pathway or a disease state. Methods Mol. Biol., 1182, 321-359.DOI: 10.1007/978-1-4939-1062-5 27

Avguštin, G., Wright, F., \& Flint, H. J. (1994). Genetic diversity and phylogenetic relationships among strains of Prevotella (Bacteroides) ruminicola from the rumen. Int. J. Syst. Bacteriol., 44, 246-255.D0I: 10.1099/00207713$\underline{44-2-246}$

Bagóné Vántus, V., Dalle Zotte, A., Cullere, M., Bónai, A., Dal Bosco, A., Szendrő, Z., Tornyos, G., Pósa, R., Bóta, B., Kovács, M., \& Zsolnai, A. (2018). Quantitative PCR with 16S rRNA-gene-targeted specific primers for analysis of caecal microbial community in growing rabbits after dietary supplementation of thyme (Thymus vulgaris) and spirulina (Arthrospira platensis). Ital. J. Anim. Sci., 17, 657-665. D0I: 10.1080/1828051X.2017.1400413

Bainbridge, M. L., Cersosimo, L. M., Wright, A. D. G., \& Kraft, J. (2016). Rumen bacterial communities shift across a lactation in Holstein, Jersey and Holstein $\times$ Jersey dairy cows and correlate to rumen function, bacterial fatty acid composition and production parameters. FEMS Microbiol. Ecol., 92. DOI: 10.1093/femsec/fiw059

Baker, B. J., Sheik, C. S., Taylor, C. A., Jain, S., Bhasi, A., Cavalcoli, J. D., \& Dick, G. J. (2013). Community transcriptomic assembly reveals microbes that contribute to deep-sea carbon and nitrogen cycling. ISME J., 7, 1962-1973. DOI: $\underline{10.1038 / \text { ismej.2013.85 }}$

Bartlett, J. M. S.; Stirling, D. (2003). "A Short History of the Polymerase Chain Reaction". PCR Protocols. Methods Mol. Biol., 226, 3-6. DOI: $10.1385 / 1-59259-384-4: 3$

Bathe, B., Bartels, D., Bischoff, N., Bott, M., Burko, A., Dusch, N., Wiegra, I. (2003). The complete Corynebacterium glutamicum ATCC 13032 genome sequence and its impact on the production of L -aspartate-derived amino acids and vitamins. J. Biotechnol., 104, 5-25. DOI: $10.1101 /$ gr.120618.111

Benson, A. K., Kelly, S. A., Legge, R., Ma, F., Low, S. J., Kim, J., Pomp, D. (2010). Individuality in gut microbiota composition is a complex polygenic trait shaped by multiple environmental and host genetic factors. Proc. Natl. Acad. Sci., 107, 18933-18938. DOI: 10.1073/pnas.1007028107

Berg Miller, M. E., Yeoman, C. J., Chia, N., Tringe, S. G., Angly, F. E., Edwards, R. A., ... White, B. A. (2012). Phage-bacteria relationships and CRISPR elements revealed by a metagenomic survey of the rumen microbiome. Environ. Microbiol., 14, 207-227. DOI: 10.1111/j.1462-2920.2011.02593.X

Boots, B., Lillis, L., Clipson, N., Petrie, K., Kenny, D. A., Boland, T. M., \& Doyle, E. (2013). Responses of anaerobic rumen fungal diversity (phylum Neocallimastigomycota) to changes in bovine diet. J. Appl. Microbiol., 114, 626-635. DOI: $10.1111 /$ jam.12067

Brenner, S., Johnson, M., Bridgham, J., Golda, G., Lloyd, D. H., Johnson, D., ... Corcoran, K. (2000). Gene expression analysis by massively parallel signature sequencing (MPSS) on microbead arrays. Nat. Biotechnol. DOI: $\underline{10.1038 / 76469}$ 
Brulc, J. M., Antonopoulos, D. A., Berg Miller, M. E., Wilson, M. K., Yannarell, A. C., Dinsdale, E. A., White, B. A. (2009). Gene-centric metagenomics of the fiber-adherent bovine rumen microbiome reveals forage specific glycoside hydrolases. Proc. Natl. Acad. Sci., 106, 1948-1953. DOI: 10.1073/pnas.0806191105

Buermans, H. P. J., \& den Dunnen, J. T. (2014). Next generation sequencing technology: Advances and applications. Biochimica et Biophysica Acta - Molecular Basis of Disease. DOI: 10.1016/j.bbadis.2014.06.015

Callaway, T. R., Dowd, S. E., Edrington, T. S., Anderson, R. C., Krueger, N., Bauer, N., Nisbet, D. J. (2010). Evaluation of bacterial diversity in the rumen and feces of cattle fed different levels of dried distillers grains plus solubles using bacterial tag-encoded FLX amplicon pyrosequencing. J. Anim. Sci., 88, 3977-3983. DOI: 10.2527/jas.2010-2900

Chaucheyras-Durand, F. F., \& Ossa, F. (2014). The rumen microbiome: Composition, abundance, diversity, and new investigative tools. The Prof. Anim. Sci., 30(1), 1-12. DOI: 10.15232/s1080-7446(15)30076-0

Chaucheyras-Durand, F., Chevaux, E., Martin, C., \& Forano, E. (2012). Use of Yeast Probiotics in Ruminants: Effects and Mechanisms of Action on Rumen pH, Fibre Degradation, and Microbiota According to the Diet. In Probiotic Anim. (pp. 119-162). DOI: $10.5772 / 50192$

Cotta, M. A. (1988). Amylolytic activity of selected species of ruminal bacteria. Appl. Environ. Microbiol.

Dang, H. A., Zsolnai, A., Kovacs, M., Bors, I., Bonai, A., Bota, B., \& Szabóoo-Fodor, J. (2017). In vitro interaction between fumonisin B1and the intestinal microflora of pigs. Pol. J. Microbiol., 66, 245-250. D0I: 10.1002/jps.2600791210

De Menezes, A. B., Lewis, E., O'Donovan, M., O'Neill, B. F., Clipson, N., \& Doyle, E. M. (2011). Microbiome analysis of dairy cows fed pasture or total mixed ration diets. FEMS Microbiol. Ecol., 78, 256-265. DOI: 10.1111/ji.15746941.2011.01151.x

Dehority, B. A. (2003). Rumen Microbiology. Nottingham, UK. Nottingham University Press.

Denman, S. E., \& McSweeney, C. S. (2006). Development of a real-time PCR assay for monitoring anaerobic fungal and cellulolytic bacterial populations within the rumen. FEMS Microbiol. Ecol., 58, 572-582. DOI: 10.1111/j.15746941.2006.00190.x

Di Bella, J. M., Bao, Y., Gloor, G. B., Burton, J. P., \& Reid, G. (2013). High throughput sequencing methods and analysis for microbiome research. J. Microbiol. Methods, 95, 401-414. D0I: 10.1016/j.mimet.2013.08.011

Dowd, S. E., Callaway, T. R., Wolcott, R. D., Sun, Y., McKeehan, T., Hagevoort, R. G., \& Edrington, T. S. (2008). Evaluation of the bacterial diversity in the feces of cattle using $16 \mathrm{~S}$ rDNA bacterial tag-encoded FLX amplicon pyrosequencing (bTEFAP). BMC Microbiol, 8. DOI: 10.1186/1471-2180-8-125

Earl, J. P., Adappa, N. D., Krol, J., Bhat, A. S., Balashov, S., Ehrlich, R. L., ... Mell, J. C. (2018). Species-level bacterial community profiling of the healthy sinonasal microbiome using Pacific Biosciences sequencing of full-length $16 \mathrm{~S}$ rRNA genes. bioRxiv, 338731. DOI: 10.1101/338731

Edwards, J. E., Kingston-Smith, A. H., Jimenez, H. R., Huws, S. A., Skøt, K. P., Griffith, G. W., ... Theodorou, M. K. (2008). Dynamics of initial colonization of nonconserved perennial ryegrass by anaerobic fungi in the bovine rumen. FEMS Microbiol. Ecol., 66, 537-545. DOI: 10.1111/j.1574-6941.2008.00563.x

Foroozandeh, A. D., Rezaeian, M., Balaly, G. R., \& Alikhani, M. (2009). Relative contributions of Rumimil Bacteria, Protozoa and Fungi to degradation of forage fiber fractions. J. Anim. Vet. Adv.,

Franzosa, E. A., Morgan, X. C., Segata, N., Waldron, L., Reyes, J., Earl, A. M., Huttenhower, C. (2014). Relating the metatranscriptome and metagenome of the human gut. Proc. Natl. Acad. Sci., 111, E2329-E2338. DOI: 10.1073/pnas. 1319284111

Freeman, W. M., Walker, S. J., \& Vrana, K. E. (1999). Quantitative RT-PCR: Pitfalls and potential. BioTechniques, DOI: $10.2144 / 99261 r v 01$

Fuks, G., Elgart, M., Amir, A., Zeisel, A., Turnbaugh, P. J., Soen, Y., \& Shental, N. (2018). Combining 16 S rRNA gene variable regions enables high-resolution microbial community profiling. Microbiome, 6. DOI: 10.1186/s40168-0170396-x

Gilbert, R. A., \& Klieve, A. V. (2015). Ruminal viruses (bacteriophages, archaeaphages). In Rumen Microbiology: From Evolution to Revolution. DOI: 10.1007/978-81-322-2401-3_9

Gilbert, R. A., Kelly, W. J., Altermann, E., Leahy, S. C., Minchin, C., Ouwerkerk, D., \& Klieve, A. V. (2017). Toward understanding phage: Host interactions in the rumen; complete genome sequences of lytic phages infecting rumen bacteria. Front. Microbiol., 8. DOI: 10.3389/fmicb.2017.02340

Ginzinger, D. G. (2002). Gene quantification using real-time quantitative PCR: An emerging technology hits the mainstream. Experimental Hematology, 30, 503-512. DOI: 10.1016/S0301-472X (02)00806-8

Glendinning, L., Collie, D., Wright, S., Rutherford, K. M. D., \& McLachlan, G. (2017). Comparing microbiotas in the upper aerodigestive and lower respiratory tracts of lambs. Microbiome, 5, 145. DOI: $10.1186 / s 40168-017-0364-5$ 
Goodrich, J. K., Davenport, E. R., Clark, A. G., \& Ley, R. E. (2017). The Relationship Between the Human Genome and Microbiome Comes into View. Annu. Rev. Genet., 51, 110711-155532. DOI: 10.1146/annurev-genet-110711$\underline{155532}$

Gray, M. W., Sankoff, D., \& Cedergren, R. J. (1984). On the evolutionary descent of organisms and organelles: A global phylogeny based on a highly conserved structural core in small subunit ribosomal RNA. Nucleic Acids Res., 12, 5837-5852. DOI: 10.1093/nar/12.14.5837

Gu, M. J., Alam, M. J., Kim, S. H., Jeon, C. O., Chang, M. B., Oh, Y. K., Lee, S. S. (2011). Analysis of methanogenic archaeal communities of rumen fluid and rumen particles from Korean black goats. Anim. Sci. J., 82, 663-672. DOI: $\underline{10.1111 / j .1740-0929.2011 .00890 . x}$

Gutell, R. R., Weiser, B., Woese, C. R., \& Noller, H. F. (1985). Comparative Anatomy of 16-S-like Ribosomal RNA. Prog. Nucleic Acid Res. Mol. Biol., 32, 155-216. D0I: 10.1016/S0079-6603(08)60348-7

Han, X., Yang, Y., Yan, H., Wang, X., Qu, L., \& Chen, Y. (2015). Rumen bacterial diversity of 80 to 110 -day- Old goats using 16s rRNA sequencing. PLoS One., 10. DOI: 10.1371/journal.pone.0117811

Henderson, G., Cox, F., Ganesh, S., Jonker, A., Young, W., \& Janssen, P. H. (2016). Erratum: Erratum: Rumen microbial community composition varies with diet and host, but a core microbiome is found across a wide geographical range. Sci. Rep., 5, 14567. DOI: $10.1038 / \operatorname{srep} 19175$

Hess, M., Sczyrba, A., Egan, R., Kim, T. W., Chokhawala, H., Schroth, G., Rubin, E. M. (2011). Metagenomic discovery of biomass-degrading genes and genomes from cow rumen. Sci., 331, 463-467. DOI: 10.1126/science.1200387

Hino, T., \& Russell, J. B. (1987). Relative contributions of ruminal bacteria and protozoa to the degradation of protein in vitro. J. Anim. Sci., DOI: 10.2527/jas1987.641261x

Huber, J. A., Morrison, H. G., Huse, S. M., Neal, P. R., Sogin, M. L., \& Mark Welch, D. B. (2009). Effect of PCR amplicon size on assessments of clone library microbial diversity and community structure. Environ. Microbiol., 11, 12921302. DOI: $10.1111 / j .1462-2920.2008 .01857 . x$

Hungate, R. E. (2013). The Rumen Bacteria. In; The Rumen and its Microbes. DOI: 10.1016/b978-1-4832-3308$\underline{6.50005-\mathrm{X}}$

Iakiviak, M., Mackie, R. I., \& Cann, I. K. O. (2011). Functional analyses of multiple lichenin-degrading enzymes from the rumen bacterium Ruminococcus albus 8. Appl. Environ. Microbiol., 77, 7541-7550. DOI: 10.1128/AEM.06088-11

Ishaq, S. L., \& Wright, A.-D. G. (2014). Design and validation of four new primers for Next-Generation Sequencing to target the $18 \mathrm{~S}$ rRNA genes of gastrointestinal ciliate Protozoa. Appl. Environ. Microbiol., 80, 5515-5521. DOI: 10.1128/aem.01644-14

Jami, E., \& Mizrahi, I. (2012). Composition and similarity of bovine rumen microbiota across individual animals. PLoS One, 7. DOI: $10.1371 /$ journal.pone.0033306

Jarvis, G. N., Kurtovic, A., Hay, A. G., \& Russell, J. B. (2001). The physiological and genetic diversity of bovine Streptococcus bovis strains. FEMS Microbiol. Ecol., 35, 49-56. DOI: 10.1016/S0168-6496(00)00110-0

Jiang, Y., Xiong, X., Danska, J., \& Parkinson, J. (2016). Metatranscriptomic analysis of diverse microbial communities reveals core metabolic pathways and microbiomespecific functionality. Microbiome, 4. DOI: 10.1186/s40168$\underline{015-0146-X}$

Jiao, J., Huang, J., Zhou, C., \& Tan, Z. (2015). Taxonomic identification of ruminal epithelial bacterial diversity during rumen development in goats. Appl. Environ. Microbiol., 81, 3502-3509. DOI: 10.1128/AEM.00203-15

Jongeneel, C. V., Delorenzi, M., Iseli, C., Zhou, D., Haudenschild, C. D., Khrebtukova, I., ... Vasicek, T. J. (2005). An atlas of human gene expression from massively parallel signature sequencing (MPSS). Genome Res. DOI: $\underline{10.1101 / g r .4041005}$

Kamra, D. N. (2005). Rumen microbial ecosystem. Current Science.

Karnati, S. K. R., Yu, Z., Sylvester, J. T., Dehority, B. A., Morrison, M., \& Firkins, J. L. (2003). Technical note: Specific PCR amplification of protozoal $18 \mathrm{~S}$ rDNA sequences from DNA extracted from ruminai samples of cows. J. Anim. Sci., 81, 812-815. DOI: $10.2527 / 2003.813812 x$

Khayalethu, N. (2013). Identifying bacteria and studying bacterial diversity using the 16S ribosomal RNA gene-based sequencing techniques: A review. African J. Microbiol. Res., 7, 5533-5540. DOI: 10.5897/AJMR2013.5966

Kim, M., Morrison, M., \& Yu, Z. (2011). Evaluation of different partial 16S rRNA gene sequence regions for phylogenetic analysis of microbiomes. J. Microbiol. Methods., 84, 81-87. DOI: 10.1016/j.mimet.2010.10.020

Klieve, A. V., Heck, G. L., Prance, M. A., \& Shu, Q. (1999). Genetic homogeneity and phage susceptibility of ruminal strains of Streptococcus bovis isolated in Australia. Lett. Appl. Microbiol., 29, 108-112. DOI: 10.1046/j.1365$\underline{2672.1999 .00596 . x}$ 
Klindworth, A., Pruesse, E., Schweer, T., Peplies, J., Quast, C., Horn, M., \& Glöckner, F. O. (2013). Evaluation of general $16 \mathrm{~S}$ ribosomal RNA gene PCR primers for classical and next-generation sequencing-based diversity studies. Nucleic Acids Res., 41. DOI: $10.1093 /$ nar/gks808

Krause, D. O., Denman, S. E., Mackie, R. I., Morrison, M., Rae, A. L., Attwood, G. T., \& McSweeney, C. S. (2003). Opportunities to improve fiber degradation in the rumen: Microbiology, ecology, and genomics. FEMS Microbiol. Rev., DOI: $10.1016 / S 0168-6445(03) 00072-X$

Krause, D. O., Nagaraja, T. G., Wright, A. D. G., \& Callaway, T. R. (2013). Board-invited review: Rumen microbiology: Leading the way in microbial ecology. J. Anim. Sci., DOI: 10.2527/jas.2012-5567

Leahy, S. C., Kelly, W. J., Ronimus, R. S., Wedlock, N., Altermann, E., \& Attwood, G. T. (2013). Genome sequencing of rumen bacteria and archaea and its application to methane mitigation strategies. Intl. J. Anim. Biosci., DOI: $10.1017 /$ S1751731113000700

Leng, J., Xie, L., Zhu, R., Yang, S., Gou, X., Li, S., \& Mao, H. (2011). Dominant bacterial communities in the rumen of Gayals (Bos frontalis), Yaks (Bos grunniens) and Yunnan Yellow Cattle (Bos taurs) revealed by denaturing gradient gel electrophoresis. Mol. Biol. Rep., 38, 4863-4872. DOI: 10.1007/s11033-010-0627-8

Li, F., Neves, A. L. A., Ghoshal, B., \& Guan, L. L. (2017). Mining metagenomic and metatranscriptomic data for clues about microbial metabolic functions in ruminants 1. J. Dairy Sci., DOI: $10.3168 / \mathrm{jds.2017-13356}$

Li, M., Penner, G. B., Hernandez-Sanabria, E., Oba, M., \& Guan, L. L. (2009). Effects of sampling location and time, and host animal on assessment of bacterial diversity and fermentation parameters in the bovine rumen. J. Appl. Microbiol., 107. 1924-1934. DOI: 10.1111/j.1365-2672.2009.04376.X

Li, R. W., Connor, E. E., Li, C., Baldwin Vi, R. L., \& Sparks, M. E. (2012). Characterization of the rumen microbiota of preruminant calves using metagenomic tools. Environ. Microbiol., 14, 129-139. DOI: 10.1111/j.14622920.2011.02543.x

Liggenstoffer, A. S., Youssef, N. H., Couger, M. B., \& Elshahed, M. S. (2010). Phylogenetic diversity and community structure of anaerobic gut fungi (phylum Neocallimastigomycota) in ruminant and non-ruminant herbivores. ISME J., 4, 1225-1235. DOI: 10.1038/ismej.2010.49

Logares, R., Sunagawa, S., Salazar, G., Cornejo-Castillo, F. M., Ferrera, I., Sarmento, H., Acinas, S. G. (2014). Metagenomic $16 \mathrm{~S}$ rDNA Illumina tags are a powerful alternative to amplicon sequencing to explore diversity and structure of microbial communities. Environ. Microbiol., 16, 2659-2671. DOI: 10.1111/1462-2920.12250

Malmuthuge, N., Griebel, P. J., \& Guan, L. L. (2014). Taxonomic identification of commensal bacteria associated with the mucosa and digesta throughout the gastrointestinal tracts of preweaned calves. Appl. Environ. Microbiol., 80, 2021-2028. DOI: $10.1128 / A E M .03864-13$

Martínez, A., Ventouras, L. A., Wilson, S. T., Karl, D. M., \& DeLong, E. F. (2013). Metatranscriptomic and functional metagenomic analysis of methylphosphonate utilization by marine bacteria. Front. Microb., 4. DOI: $\underline{10.3389 / \text { fmicb.2013.00340 }}$

Mason, O. U., Scott, N. M., Gonzalez, A., Robbins-Pianka, A., Bælum, J., Kimbrel, J., Jansson, J. K. (2014). Metagenomics reveals sediment microbial community response to Deepwater Horizon oil spill. ISME J., 8, 1464-1475. DOI: 10.1038/ismej.2013.254

Matthews, C., Crispie, F., Lewis, E., Reid, M., O’Toole, P. W., \& Cotter, P. D. (2018). The rumen microbiome: a crucial consideration when optimising milk and meat production and nitrogen utilization efficiency. Gut Microbes, 1-18. 10.1080/19490976.2018.1505176

McCann, J. C., Wickersham, T. A., \& Loor, J. J. (2014). High-throughput methods redefine the rumen microbiome and its relationship with nutrition and metabolism. Bioinf. Biol. Insights., 10.4137/BBIi.Ss15389

McGovern, E., Waters, S. M., Blackshields, G., \& McCabe, M. S. (2018). Evaluating established methods for Rumen $16 \mathrm{~S}$ rRNA amplicon sequencing with mock microbial populations. Front. Microbiol., 9(JUN). DOI: 10.3389/fmicb.2018.01365

McSweeney, C. S., Denman, S. E., Wright, A. D. G., \& Yu, Z. (2007). Application of recent DNA/RNA-based techniques in rumen ecology. Asian-Aust. J. Anim. Sci., 20, 283-294. DOI: 10.5713/ajas.2007.283

Mobashar, M., Hummel, J., Blank, R., \& Südekum, K. H. (2019). Contribution of different rumen microbial groups to gas, short-chain fatty acid and ammonium production from different diets - an approach in an in vitro fermentation system. J. Anim. Physiol. Anim. Nutr. DOI: 10.1111/jpn.12996

Morgavi, D. P., Kelly, W. J., Janssen, P. H., \& Attwood, G. T. (2013). Rumen microbial (meta) genomics and its application to ruminant production. In Anim., 7, 184-201. DOI: $10.1017 / S 1751731112000419$

Morrison, M., K. E. Nelson, D. Antonopoulos, B. Cheng, E. Devillard, D. E. Goodheart, H. S. Jun, V. Parisi, J. S. Park, S. M. Qi, C. Reveneau, I. K. O. Cann, S. Daugherty, C. W. Forsberg, I. Hance, R. I. Mackie, W. C. Nelson, J. B. Russell, B. A. 
White and D. B. Wilson. (2003). New and emerging approaches to improve herbivore nutrition: Rumen microbiology in the genomics era. In: Proc.s 6th Intl. Symp. Nutr. Herbivores, Merida, Mexico. 6, 309-320.

Mosoni, P., Chaucheyras-Durand, F., Béra-Maillet, C., \& Forano, E. (2007). Quantification by real-time PCR of cellulolytic bacteria in the rumen of sheep after supplementation of a forage diet with readily fermentable carbohydrates: Effect of a yeast additive. J. Appl. Microbiol., 103, 2676-2685. DOI: 10.1111/j.1365-2672.2007.03517.x

Muyzer, G., de Waal, E., \& Uitterlinden, A. G. (1993). Profiling of complex microbial populations by denaturing gradient gel electrophoresis analysis of polymerase chain. Appl. Environ. Microbiol., 59, 695-700. D0I: 00992240/93/030695-06\$02.00/0

Nathani, N. M., Patel, A. K., Dhamannapatil, P. S., Kothari, R. K., Singh, K. M., \& Joshi, C. G. (2013). Comparative evaluation of rumen metagenome community using qPCR and MG-RAST. AMB Express., 3, 1-8. 10.1186/2191-0855-3-1

Petri RM, Schwaiger T, Penner GB, Beauchemin KA, Forster RJ, McKinnon JJ, McAllister TA. 2013. Changes in the rumen epimural bacterial diversity of beef cattle as affected by diet and induced ruminal acidosis. Appl. Environ. Microbiol., 79, 3744 -3755. DOI: $10.1128 / A E M .03983-12$

Pitta, D. W., Pinchak, W. E., Dowd, S. E., Osterstock, J., Gontcharova, V., Youn, E., \& Malinowski, D. P. (2010): Rumen bacterial diversity dynamics associated with changing from bermudagrass hay to grazed winter wheat diets. Microb. Ecol., 59, 511-522. DOI: 10.1007/s00248-009-9609-6.

Prescott, D. M. (1994). The DNA of ciliated protozoa. Microbiol. Rev., 58, 233-267. DOI: 10.1016/0022-2836(72)90095-2

Pushkarev, D., Neff, N. F., \& Quake, S. R. (2009). Single-molecule sequencing of an individual human genome. Nat. Biotechnol. DOI: $10.1038 /$ nbt.1561

Ransom-Jones, E., Jones, D. L., McCarthy, A. J., \& McDonald, J. E. (2012). The Fibrobacteres: An Important Phylum of Cellulose-Degrading Bacteria. Microb. Ecol., DOI: 10.1007/s00248-011-9998-1

Rasmussen, R. (2001). Quantification on the LightCycler. In Rapid Cycle Real-Time PCR. 21-34. DOI: 10.1007/978-3642-59524-03

Rédei, G. P. (2008). MPSS (multiple parallel signature sequencing). In Encycloped. Gen. Genom. Prot. and Inform. DOI: 10.1007/978-1-4020-6754-9 10815

Regensbogenova M., McEwan N. R., Javorsky P., Kisidayova S., Michalowski T., Newbold C. J., et al. (2004b). A re-appraisal of the diversity of the methanogens associated with the rumen ciliates. FEMS Microbiol. Lett., 238, 307313. DOI: $10.1111 / j .1574-6968.2004 . t b 09771 . x$

Regensbogenova, M., Kisidayova, S., Michalowski, T., Javorsky, P., Moon-Van Der Staay, S. Y., Moon-Van Der Staay, G. W. M., Pristas, P. (2004). Rapid identification of rumen protozoa by restriction analysis of amplified 18S rRNA gene. Acta Protozoologica, 43, 219-224.

Reinartz, J., Bruyns, E., Lin, J. Z., Burcham, T., Brenner, S., Bowen, B., ... Woychik, R. (2002). Technique review massively parallel signature sequencing (MPSS) as a tool for in-depth quantitative gene expression profiling in all organisms. Briefings Funct. Genomics Proteomics. DOI: $\underline{10.1093 / \mathrm{bfgp} / 1.1 .95}$

Roehe, R., Dewhurst, R. J., Duthie, C. A., Rooke, J. A., McKain, N., Ross, D. W., Wallace, R. J. (2016). Bovine Host Genetic Variation Influences Rumen Microbial Methane Production with Best Selection Criterion for Low Methane Emitting and Efficiently Feed Converting Hosts Based on Metagenomic Gene Abundance. PLoS Genetics, 12. DOI: 10.1371/journal.pgen.1005846

Roesch, L. F. W., Fulthorpe, R. R., Riva, A., Casella, G., Hadwin, A. K. M., Kent, A. D., ... Triplett, E. W. (2007). Pyrosequencing enumerates and contrasts soil microbial diversity. ISME J., 1, 283-290. DOI: 10.1038/ismej.2007.53

Rohwer, F., Prangishvili, D., \& Lindell, D. (2009). Roles of viruses in the environment. Environ. Microbiol. DOI: 10.1111/j.1462-2920.2009.02101.x

Rooks, M. G., Veiga, P., Wardwell-Scott, L. H., Tickle, T., Segata, N., Michaud, M., Garrett, W. S. (2014). Gut microbiome composition and function in experimental colitis during active disease and treatment-induced remission. ISME J., 8, 1403-1417. DOI: 10.1038/ismej.2014.3

Ross, E. M., Moate, P. J., Bath, C. R., Davidson, S. E., Sawbridge, T. I., Guthridge, K. M., Hayes, B. J. (2012). High throughput whole rumen metagenome profiling using untargeted massively parallel sequencing. BMC Genet., 13. DOI: 10.1186/1471-2156-13-53

Ross, E. M., Moate, P. J., Marett, L., Cocks, B. G., \& Hayes, B. J. (2013b). Investigating the effect of two methane-mitigating diets on the rumen microbiome using massively parallel sequencing. J. Dairy Sci., 96, 6030-6046. DOI: 10.3168/jds.2013-6766

Ross, E. M., Moate, P. J., Marette, L. C., Cocks, B. G., \& Hayes, B. J. (2013a). Metagenomic predictions: from microbiome to complex health and environmental phenotypes in humans and cattle. PLOSone, 8, e73056. D0I: $0.1371 /$ journal.pone.0073056 
Russell, J. B. (2009). Rumen. In Encyclopedia of Microbiology. DOI: 10.1016/b978-012373944-5.00061-4

Salonen A, Lahti L, SalojaÈ rvi J, Holtrop G, Korpela K, Duncan SH, et al. (2014). Impact of diet and individual variation on intestinal microbiota composition and fermentation products in obese men. The ISME J., 8. DOI: 10.1038/ismej.2014.63

Schlegel, L., Grimont, F., Ageron, E., Grimont, P. A. D., \& Bouvet, A. (2003). Reappraisal of the taxonomy of the Streptococcus bovis/Streptococcus equinus complex and related species: Description of Streptococcus gallolyticus subsp. gallolyticus subsp. nov., S. gallolyticus subsp. macedonicus subsp. nov. and S. gallolyticus subsp. pasteurianus subsp. nov. Int. J. Syst. Evol. Microbiol., 53, 631-645. DOI: 10.1099/ijs.0.02361-0

Schofield, P. (2000). Gas production methods. In J. P. F. D’Mello (Ed.), Farm animal metabolism and nutrition (pp. 209232). Wallingford, UK: CABI Publishing.

Shin, E. C., Cho, K. M., Lim, W. J., Hong, S. Y., An, C. L., Kim, E. J., ... Yun, H. D. (2004). Phylogenetic analysis of protozoa in the rumen contents of cow based on the 18S rDNA sequences. J. Appl. Microbiol., 97, 378-383. DOI: 10.1111/j.1365-2672.2004.02304.x

Shokralla, S., Spall, J. L., Gibson, J. F., \& Hajibabaei, M. (2012). Next-generation sequencing technologies for environmental DNA research. Mol. Ecology. DOI: 10.1111/j.1365-294X.2012.05538.x

Skillman L. C., Toovey A. F., Williams A. J., Wright A.-D. G. (2006). Development and validation of a real-time PCR method to quantify rumen protozoa and examination of variability between Entodinium populations in sheep offered a hay-based diet. Appl. Environ. Microbiol., 72, 200-206. DOI: 10.1128/AEM.72.1.200-206.2006

Sluijter, J. P. G., Pasterkamp, G., \& De Kleijn, D. P. V. (2006). Quantitative real-time PCR. In Cardiovascular Research: New Technologies, Methods, and Applications (pp. 75-83). D0I: 10.1007/0-387-23329-6 4

Stevenson DM, Weimer PJ (2007). Dominance of Prevotella and low abundance of classical ruminal bacterial species in the bovine rumen revealed by relative quantification real-time PCR. Appl. Microbiol. Biotechnol., 75: 165-174.

Stewart, C. S., \& Bryant, M. P. (1988). The rumen bacteria. In P. N. Hobson (Ed.). The Rumen Microbial System (pp. $21-$ 75). London: Elsevier Applied Science.

Stewart, R. D., Auffret, M. D., Warr, A., Wiser, A. H., Press, M. O., Langford, K. W., ... Watson, M. (2018). Assembly of 913 microbial genomes from metagenomic sequencing of the cow rumen. Nat. Commun., DOI: 10.1038/s41467-018$\underline{03317-6}$

Stewart, R., Auffret, M. D., Warr, A., Snelling, T., Dewhurst, R., Walker, A. W., Watson, M. (2017). Assembly of hundreds of microbial genomes from the cow rumen reveals novel microbial species encoding enzymes with roles in carbohydrate metabolism. bioRxiv. DOI: $10.1101 / 162578$

Suchodolski, J. S. (2012). Chapter 2: Gastrointestinal Microbiota. Canine and Feline Gastroenterology. DOI: 10.1016/B978-1-4160-3661-6.00002-X

Sylvester J. T., Karnati S. K. R., Dehority B. A., Morrison M., Smith G. L., St-Pierre N. R., et al. (2009). Rumen ciliated protozoa decrease generation time and adjust $18 \mathrm{~S}$ ribosomal DNA copies to adapt to decreased transfer interval, starvation, and monensin. J. Dairy Sci. 92, 256-269. DOI: 10.3168/jds.2008-1417

Sylvester, J. T., Karnati, S. K. R., Yu, Z., Morrison, M., \& Firkins, J. L. (2004). Development of an assay to quantify rumen ciliate protozoal biomass in cows using real-time PCR. J. Nutr., 134, 3378-3384. DOI: 10.1093/in/134.12.3378

Székely, A. J., Sipos, R., Berta, B., Vajna, B., Hajdú, C., \& Márialigeti, K. (2009). DGGE and T-RFLP analysis of bacterial succession during mushroom compost production and sequence-aided T-RFLP profile of mature compost. Microb. Ecol., 57, 522-533. DOI: 10.1007/s00248-008-9424-5

Tajima, K., Aminov, R. I., Nagamine, T., Matsui, H., Nakamura, M., \& Benno, Y. (2001). Diet-Dependent Shifts in the Bacterial Population of the Rumen Revealed with Real-Time PCR. Appl. Environ. Microbiol., 67, 2766-2774. DOI: 10.1128/AEM.67.6.2766-2774.2001

Tapio, I., Fischer, D., Blasco, L., Tapio, M., Wallace, R. J., Bayat, A. R., Vilkki, J. (2017). Taxon abundance, diversity, cooccurrence and network analysis of the ruminal microbiota in response to dietary changes in dairy cows. PLoS ONE, 12. DOI: 10.1371/journal.pone.0180260

Tewari, D., Cieply, S., \& Livengood, J. (2011). Identification of bacteria recovered from animals using the 16s ribosomal RNA gene with pyrosequencing and Sanger sequencing. J. Vet. Diag. Invest., 23, 1104-1108. DOI: $10.1177 / 1040638711425583$

Tveit, A. T., Urich, T., \& Svenning, M. M. (2014). Metatranscriptomic analysis of arctic peat soil microbiota. Appl. Environ. Microbiol., 80, 5761-5772. DOI: 10.1128/AEM.01030-14

Tymensen L., Barkley C., McAllister T. A. (2012b). Relative diversity and community structure analysis of rumen protozoa according to T-RFLP and microscopic methods J. Microbiol. Methods., 88, 1-6. DOI: 10.1016/j.mimet.2011.09.005v 
Tymensen, L., Barkley, C., \& McAllister, T. A. (2012). Relative diversity and community structure analysis of rumen protozoa according to T-RFLP and microscopic methods. J. micorbiol. Methods., 88, 1-6. DOI: 10.1016/j.mimet.2011.09.005

Urich, T., Lanzén, A., Qi, J., Huson, D. H., Schleper, C., \& Schuster, S. C. (2008). Simultaneous assessment of soil microbial community structure and function through analysis of the meta-transcriptome. PLoS One, 3. DOI: 10.1371/journal.pone.0002527

VanGuilder, H. D., Vrana, K. E., \& Freeman, W. M. (2008). Twenty-five years of quantitative PCR for gene expression analysis. BioTechniques. DOI: $10.2144 / 000112776$

Walsh, P., Palu, C., Kelly, B., Lawor, B., Wassan, J. T., Zheng, H., \& Wang, H. (2017). A metagenomics analysis of rumen microbiome. In Proceedings - 2017 IEEE International Conference on Bioinformatics and Biomedicine, BIBM 2017. 2077-2082. DOI: 10.1109/BIBM.2017.8217980

Wanapat, M., \& Cherdthong, A. (2009). Use of real-time PCR technique in studying rumen cellulolytic bacteria population as affected by level of roughage in swamp buffalo. Curr. Microbiol., 58, 294-299. DOI: 10.1007/s00284-008$\underline{9322-6}$

Wang, L., Wu, D., Yan, T., \& Wang, L. (2018). The impact of rumen cannulation on the microbial community of goat rumens as measured using 16S rRNA high-throughput sequencing. J. Anim. Physiol. Anim. Nutr., 102, $175-183$. DOI: $\underline{10.1111 / \text { ipn.12676 }}$

Yang, B., Wang, Y., \& Qian, P. Y. (2016). Sensitivity and correlation of hypervariable regions in 16S rRNA genes in phylogenetic analysis. BMC Bioinf., 17. DOI: 10.1186/s12859-016-0992-y

Yang, L. Y., Chen, J., Cheng, X. L., Xi, D. M., Yang, S. L., Deng, W. D., \& Mao, H. M. (2010). Phylogenetic analysis of 16S rRNA gene sequences reveals rumen bacterial diversity in Yaks (Bos grunniens). Mol. Biol. Rep., 37, 553-562. DOI: $10.1007 / s 11033-009-9794-x$

Yu, Y., Lee, C., Kim, J., \& Hwang, S. (2005). Group-specific primer and probe sets to detect methanogenic communities using quantitative real-time polymerase chain reaction. Biotechnol. Bioeng., 89, 670-679. D0I: $10.1002 /$ bit.20347

Zhou, M., Chen, Y., \& Guan, L. L. (2015). Rumen bacteria. In Rumen Microbiology: From Evolution to Revolution. DOI: $\underline{10.1007 / 978-81-322-2401-3 ~} 6$

Zhou, X., Li, Y., Liu, S., Yang, Q., Su, X., Zhou, L., ... Huang, Q. (2013). Ultra-deep sequencing enables high-fidelity recovery of biodiversity for bulk arthropod samples without PCR amplification. GigaScience. DOI: 10.1186/2047-217X-2-4 